\title{
4 X 3 X 2 = QUADRANGULATING TRIANGULAR PAIRS: SIMULTANEOUS VERSIONS OF A VITAL CONCRETE POEM
}

\author{
Charles A. Perrone
}

Untranslatability is more associated with poetry than any other genre because of its formal features-rhyme, meter, paronomasia inter alia-whose functionality so often depends on idiosyncratic qualities of a given language. ${ }^{1}$ The difficulties suggested in Roman Jakobson's categorical affirmation that "poetry by definition is untranslatable” (113) and in Robert Frost's definition of poetry as "what gets lost in translation” are compounded further in the synthetic minimalism of Brazilian concrete poetry, as each poem aims to be a selfsufficient structure of linguistic relations, as opposed to a vehicle of mood, rhythmic emotivity, or meaning. Each instance of composition should be a unique, original event, a sui generis verbivocovisual ideogram that by its very nature would pose extreme if not insurmountable challenges to the prospect of satisfactory rendition in another language. Still, the Brazilian originators of poesia concreta indeed sought to see their work rendered in other tongues in order to enhance visibility for the movement and to increase circulation of their neo-vanguard output. Moreover, the poets of the São Paulo Noigandres group-Décio Pignatari, Augusto de Campos, and Haroldo de Campos-also distinguished themselves as translators of all manner of lyric, from troubadour texts, baroque sonnets, and romantic adventures to mellifluous symbolism, avant-garde experiments, and even Chinese ideograms, for which Ezra Pound was a model. To refer to their own practice of translation of select poetry of invention-with express acceptance of the statute of generic impossibility and the imperative of re-imagining aesthetic information - the Campos brothers coined such terms as

\footnotetext{
${ }^{1}$ In these pages I return to ideas that first surfaced in my domain when Haroldo de Campos was visiting professor at the University of Texas in 1981 and some local poetry circles pondered his output, including classic concrete poems and the feasibility of translation. Some of the thoughts expressed here have been simmering since then, while others have been provoked by recent developments in translation studies and poetics, Brazilian varieties. I am grateful to André Vallias and Claus Clüver for their advice and assistance with materials for this undertaking.
} 
transcriação (transcreation) and tradução-arte (art-translation). ${ }^{2}$ Their advancement of alternative ideas for translation of inventive originals may also lead to new possibilities for crafting versions of concrete poetry. To this end, one may turn to Jakobson's notion of “intersemiotic translation” (113), or transmutation from one sign system to another, from the verbal to the non-verbal, which in the case of art for the page means graphic register.

In the creative repertory of poesia concreta, one of the most distinguished items is "nascemorre" [isborndies] (1956) by Haroldo de Campos, which is meticulously built upon geometrical designs (see Cluver 1981). Tightly-woven and terse, the text constitutes two pairs of triangular sets of four lines. The first pivotal point is se (pronominal one, if), whose ambivalence, coupled with the necessity for the auxiliary verb with English "born,” precludes an obliging Anglophone rendition in the same verbal mode. Several other translational conundrums emerge from the extreme concision of the poem and its phono-semantic mirrors. There are four extant English translations, each with its own measure and balance of advantages and drawbacks, but none truly solves the basic dilemma posed by the "duplicity" of se. A potential integral response to this situation would be to offer co-extant versions, each designed to contain equivalencies of essential components of the original. Just as the whole original poem has four sectors, the multi-part translation would be not one unitary, exclusive version but four simultaneous mutually inclusive complete versions, all members (arms and legs) of one mega-meta-translation, in sum, a quadrangulation to achieve poetic "unicity.”

Before considering translation per se, it should be instructive to effectuate a close reading of the original poem in order to remain attentive to some of the features that an English-language version would ideally include. ${ }^{3}$ Such an exercise goes hand in hand with the Noigandres poets' Pound-derived notion of crítica via tradução, i.e. the discovery of a poem's unique qualities by means of postulating solutions in a translation keen as much to sound, shape, and interrelations as to any component of signification. Haroldo's "nascemorre" is at once one of the more "lyrical" concrete poems and an exemplary instance of planned construction.

\footnotetext{
${ }^{2}$ In Portuguese, see Campos 1969 on "creative translation" into alphabetic script of poetry made with oriental ideograms. For a synthetic account of Haroldo's approach to translation-for which he coined several different names depending on the project—see Santaella. "Da tradução à transficcionalidade” (1989) is H. Campos' most theoretical writing on this topic; therein the term transposição criativa leads to a conclusion with the neologism transfingidor [trans-pretender] and reference to the creative genius of Fernando Pessoa. In English, see the translation of Haroldo's own critical piece in NOVAS, which is the point of departure for the notion of "transcreation." For a useful diachronic account of Haroldo's approaches to translation, beginning with his readings of Pound, see Molina. On Augusto, including minute details of marvelous translations, see Britto, who questions the need for special terms for the Campos' versions, which simply comprise superb translation.
} 
nasce

morre nasce

morre nasce morre

renasce remorre renasce

remorre renasce

remorre

re

re

\section{desnasce \\ desmorre desnasce \\ desmorre desnasce desmorre}

\section{nascemorrenasce \\ morrenasce \\ morre}

se

The first step in explicating this poem to a reader/spectator not conversant with Portuguese could simply be to indicate that nasce means "is born" and that morre means "dies." With that, one should be able to imagine the meanings of the combinatory verb forms that follow and the syntagms in play: birth, death, rebirth, re-death, dis-birth, dis-death. Again, the polysemantic role of the first-last word is significant: se both means "if" and designates the impersonal subject “one” (cf. French on, Spanish uno/se). Thus one faces simultaneous doubt-uncertainty and affirmation-declaration. As far as other conjugations are concerned, while Portuguese renasce is as normal as the English phrase "is reborn," (cf. renascence), remorre [re-dies] is neologistic. The integrated lexical and conceptual strategy continues with desnasce [is un-/de-/dis-born] and desmorre [un-/de-/dis-dies]. The strangeness of these verb forms is amplified if one adds a third function for the word se, that of third-person reflexive pronoun. The Portuguese verbs nascer and morrer do not take reflexive pronouns (as the second may in Spanish, for instance), and if a reflexive se is understood to govern all the verb forms here, what results are aberrant phrases on the order of "one borns oneself," or, with the articulation of an implied subject, "it/he/she dies it/him/herself,” “you re-birth yourself,” or “you dis-die yourself.” Such undertones are less obvious, but they do work with the neologisms, repetitions and combinations in a process of

3 The following account in based on a section of Perrone, Chapter Two, "The Imperative of Invention: 
radical defamiliarization, helping to create an ambience, a mood of disquiet. By means of these verbal unfoldings, the basic human cycle of being born and dying is constituted, rather than as a progression with starting and finishing lines, as a process of continuity and circularity, with occurrences, emphases, and reversals. The objectified linguistic material of "nascemorre," through its mathematical e sets of interrelations, opens onto a subjective, even existential plane. The internal dialectic of sounding, spelling, doing, re-doing, and undoing makes strange the real-life progression toward death, and will not allow such linearity to penetrate the poem.

Semantic relationships in "nascemorre" are re-inforced in visual structures and phonoorthographic patterns. The user-consumer likely first notes the text's shape: the four parts are mirrored pairs of triangles with fields white space above and below. Some of the symmetries in this set-up are perfect, while others are near-exact or just in corresponding position. The axial points (se, re) are identical in their graphic representation, as are the numbers of syllables in counterpoised horizontal lines (1-2-4-6 / 9-6-3-1 above and vice versa below). Actual physical space occupied is one degree greater in the third triangle (the prefix des- has three letters instead of the two of re-), and it is lesser in the last triangle, since the verbal components are run together, consistent with the conjunctive spirit of the poem. The full phonetic grid has only six phonemes: /si/, /na/, /mó/, /Ri/, /Re/, /des/. The initial se (/si/) reverberates incessantly in the perfect rhyme of the second syllable of nasce (/nasi/) and derivatives; and there are vocalic rhymes in morre (/móRi/) and derivatives. Just as se seems to derive phonetically from the second syllable of nasce, the particle re- appears to be detached from morre. The word morre-connected to the counterpart nasce via the vowel /i/-links with the prefix re-via the consonant /R/. The last two letters of the other element des-, finally, are like a flip flop of se. The overall textual idea is founded on the two key syllables, re- and se-, in which spelling and normal pronunciation are at variance. In extremely formal Brazilian speech, the syllable se, whether in word-initial or word-final position, could be pronounced /se/ and thus rhyme with an equally formal word-final -re or word-initial re-pronounced /Re/. The phoneme /R/ here could manifest as the allophone of multiple flap $\mathrm{r}$ (trill) or as the velar fricative $/ \mathrm{x} /$; in either case, sound would be identical in the word morre and the prefix re-. While the spelling of the prefix des- is pertinent to patterning here, the fact that it can have several different acceptable pronunciations is not as 
significant. In any case, with all this minutiae, the sensation of verbivocovisual webbing in the poem and several challenging details for translation should be evident.

As for the typographical rendering of the poem, Claus Clüver (2007) remarks the centrality of precision in disposition and placement:

... a change of the minutest detail can destroy a major structural effect: the first triangle formed by a regular (if you like mathematical) development of the minimal verbal material ... re-constructs itself by seemingly turning over an invisible horizontal and a structurally designated vertical axis formed by carefully aligned 're's; a shift of the second triangle by one slot to the left (as happened in ...) not only removes that axis but violates the structural feature of vertically aligning all e's of the text except for those of the initial and final 'se'. Altogether the poem exhausts all the possibilities inherent in its semantic properties as well as of the visual arrangement of its triangles. The final syllable (an echo of 'nasce') returns us to the beginning in an endless progression of dying and becoming.

The first presentation of Haroldo's ethereal concrete poem in the Anglophone world included a commentary concerning its genesis, aesthetic genres, the vital, and death. It is not actually a translation but a reproduction of the original with a glossary and an authorial statement of intent in sans-serif typeface (Williams, no pagination; denasce is his typo):

$$
\text { se }=\text { if }
$$

nasce $=(\mathrm{a}$ human being $)$ is born

$$
\text { morre }=(\mathrm{a} \text { human being }) \text { dies }
$$

$$
\text { re = again }
$$

denasce $=($ a human being $)$ is unborn

$$
\text { desmorre }=\text { (a human being) } \text { undies }
$$

"Hans Arp once made the following comparison between the poetry of the painterpoet Kandinsky and the poetry of Goethe: 'A poem by Goethe teaches the reader, in a poetical way, that death and transformation are the inclusive condition of man. Kandinsky, on the contrary, places the reader before an image of dying and transforming words, before a series of dying and transforming words ...' This poem wants to be an exact presentification of that proposition. The vital cycle (or the Joycean 'vicocycle')." (H. de C.)

It is worthy of note that the lexicon is really incomplete since the meaning of se as impersonal subject is simply passed on to "a human being," and the prefix un- is preferred over the dis- morpheme very similar to des-. The parentheses do help add a sense of diversification as they may give the idea that there are implied levels in the word design. As 
for the interarts connection, having been inspired by the work of the Russian wordsmithvisual artist Wassily Kandinsky, Haroldo's poem could be considered as sympathetic to intersemiotic translation, that is from one medium to another, from the (plastic) arts to (verbal) poetry. In the context of a semiotic study of modes of translation, graphic artist Julio Plaza did a line-art interpretation of Haroldo’s poem as an instance of tradução simbólica, providing a visualization of the poematic fabric based on triangulation and representation with respective assigned graphemes of the repeating verbal segments (nasce, morre, renasce, remorre, desnasce, desmorre). In the explication, it is made clear that the translation would only be comprehensible with a "lexical key as a symbolic code" (Plaza 99-104). At the level of macrostructure, one can view two large triangles standing for life and death.

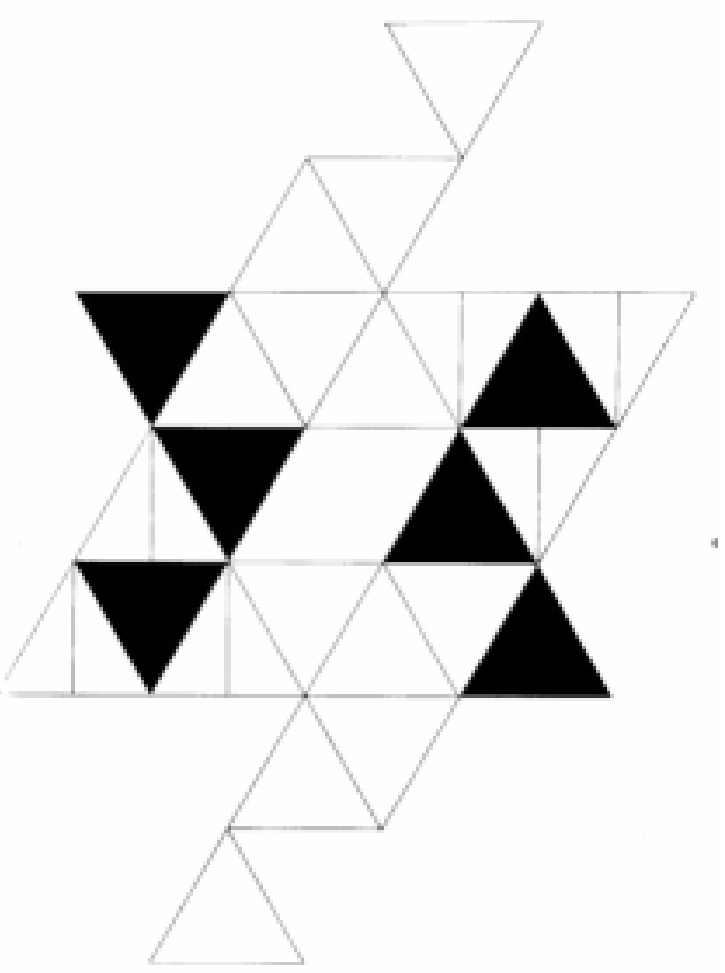

This contrastive black-white and numerical effort will provide additional impetus for the multilateral translation proposal at the conclusion of the present paper. 
The first translation per se of "nascemorre" appeared in the historic volume Concrete Poetry: A Word View, edited by Mary Ellen Solt, who co-signed with Marco Guimarães this product (104):

\section{if \\ to be born \\ to die \\ to die}

to be born

to be born to die

to be reborn to die again to be reborn

to die again to be reborn

to die again

again

not to be born

not to be dead not to be born

not to be dead not to be born not to be dead again

\author{
to be born to die to be born \\ to die to be born \\ to die \\ if
}

Keeping in mind Clüver's alert regarding spacing in the original, it is right to question decisions about lay out here. The symmetry and painstaking visual tightness of the original may be seen to suffer in this version, with its different axes and liberal utilization of spaces (instead of running words together). While the clear reliance on meaning generates expected outcomes, there are warranted solutions to certain quandaries, especially the employing of infinitives instead of conjugated verb forms. The wording "to be dead" works well with "to be born," and in sonorous conjunction some use of "re" could have been calculated. The word "again” proves to be ungainly and seems not to be a gain (puns intended) given the number of letters, its status as a stand-alone word (as opposed to morpheme), and the lack of sound reflectors. If the very triangularity of this English version could be challenged, not so the typeface, which is indeed in step with that part of the strategy of 1950s poesia concreta. A third version of "nascemorre" appeared not in an anthology of poetry but in the context of a creative expository essay for a journal in which graphic resources were surely limited and special font was not an option:

you

you're born 
you die you're born

you die you're born you die

you're reborn you redie you're reborn

you redie you're reborn

you redie

die

born

you're unborn

you undie you're unborn

you undie you're unborn you undie

you're borndieborn
youdieborn
you die
you

This is a commissioned third-party rendering (Fred Ellison) inserted (65-66) into a translation of a free-form think-piece by a friend of Haroldo's, Severo Sarduy “Toward Concreteness." The published circumstances do not help appreciation of the poem, as it is split between the bottom of one page and the top of the next (turned) page, the visual wholeness simply getting lost. Given the discursive situation, preference went to the referential function of language (to the extent that it obtains here). The conceivably literal choice of "you" for the impersonal subject (to the exclusion of "if” and "one” alike) has some agreeable consequences, such as the ring of / $\mathrm{u} /$ to duplicate the ring of $/ \mathrm{i} /$ in the original, an unusual feel in the combinations of the fourth triangle, and reflection of the semanteme of repetition in morpheme re- in the last letters of "you're."

Concrete poetry, it is always useful to bear in mind, not only pushes the poetic function of language, it activates the phatic function as well, calling attention to itself and its operations. The fourth version of "nascemorre" was realized by a specialist in concrete poetry, Antonio Sergio Bessa, co-editor of a selection of Haroldo's work in English. This translation (32) involved concerted efforts to overcome the descriptive and unbalanced aspects of earlier versions. It is sensitive to time-space issues from head to toe, with assiduous attention to sound, size, internal reflections, and the unspoken essences of the poem. 
bornoverborn

overborn

is

Visually sparse and shaped like the original, this offering sets up axes and internal equilibrium (esp. the four letters of "born” and “over”). Obviously, the impersonal subject or implied other subject is absent, and the beginning is the conjugated copulative verb. The "is" option cannot get around the predicament of the need for the auxiliary verb with "is born" vs. the simple "dies," so something was found that would fit the construction: "is over," which conveniently signifies end, and by extension death, as well as "above” in a physical, spatial sense as in fact occurs in the layout of the words. Further, "over" is the key particle in the phrase "to do [something] over," as in to redo or repeat, which dovetails with the reparadigm in the poem. Structurally, the -er of "over" allows for retention of the mirroring and flipping at the intersection with "re-born." While this solution is felicitous, as always there are unavoidable sacrifices; these include the hypothetical overture of "if" and, with the adjectival plan, the parallel uses of verbs. Also of note, in the fourth triangle there are only three lines. One is compelled to ask if this is intentional, an editorial miscue, or an oversight (pun intended), something not to be overlooked in any case. While there is no "if" in this twenty first-century rendering, the proximity of "is" to "if" raises the prospect of a variant containing that option, for a constructed "poetic I" that/who manifests not as a self/voice/persona but as a supra-personal presence, a presentification.

Each of the English versions has its respective merits and points to ponder otherwise. Given the impossibility of duplication of all the effects and interrelations of the original, as well as the architectural particularity of the poem-its four contiguous triangles of four lines each-, a novel solution can be proposed: a set of simultaneous versions of the poem each 
addressing distinct components or distinctive features. With the syntactical difference in the use of the verbs to be born and to die, not to mention the lack of simple verbal synonyms for the former, the point of departure for this experiment will be the proposition that nouns better serve the purposes of translation here, to wit: birth and death. These two items have the same number of letters and share the final two letters, as nasce and morre are the same length and share their final unstressed vowel. A first rendering could opt to favor "if”, as Haroldo did in his gloss, but add a "one” at the end to create the impersonal subject ("a human being”). Using “dis” instead of “un” more closely reproduces the original sono-morphemically, setting up short-i assonance (“if,” “-is”) and an occlusive tie, between “dis-” and “death”:

\title{
if \\ birth \\ death birth \\ death birth death
}

\section{rebirth redeath rebirth \\ redeath rebirth \\ redeath \\ re}

\author{
re \\ disbirth \\ disdeath disbirth \\ disdeath disbirth disdeath

birthdeathbirth
deathbirth
death
one

In a second member of the set, "if" and "one" can be joined at the outset and at the end, less economical than the original but semantically more true. In the interest of sound, the "un” prefix can be used to link with the dual "one.” Another desirable in this rendition would be the visual repetitions of <consonant $+\mathrm{e}>$ in "redeath" and "rebirth." To achieve mirroring in the transition from the first triangle to the second, a sequential "then" can be inserted; likewise, a "there" can conclude the first half, visually echoing the "th" of the nouns and bringing to bear the "re" to flip: 


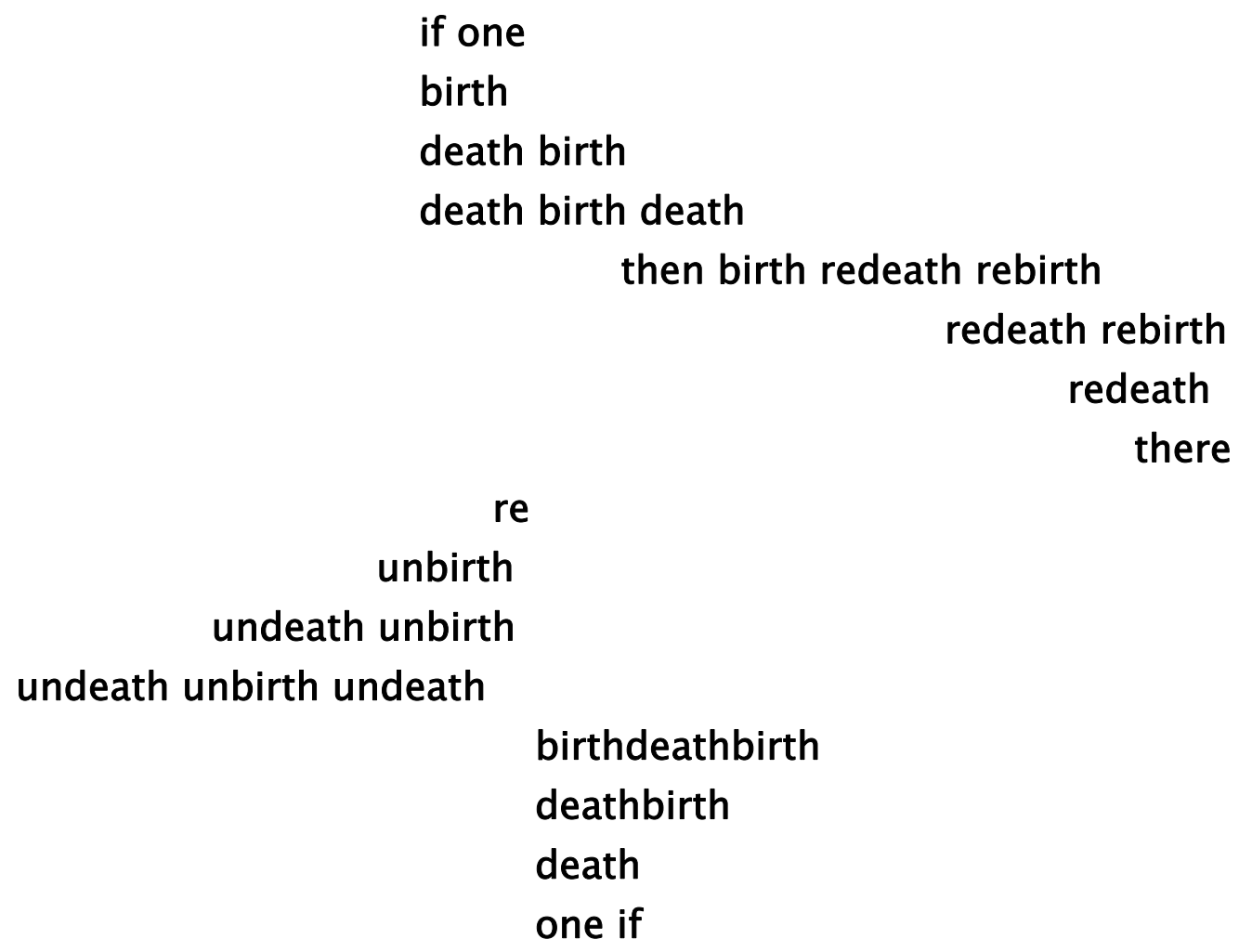

A third option could play on visual rhymes and letter coincidences by using the definite article the, to echo, assuming the desired pronunciation with $/ \mathrm{i} /$, in $d e$ - and $r e$-. If in the original the phoneme /i/ rings throughout, here it would still be loud, and the interdental consonant could prove to be dominant in parallel, hopefully compensatory fashion.

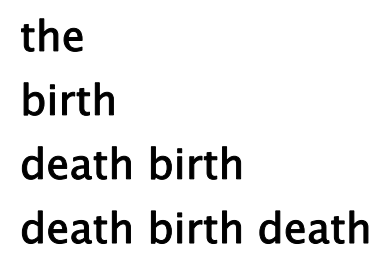

rebirth redeath rebirth

redeath rebirth

redeath

re

re

debirth

dedeath debirth

dedeath debirth dedeath

birthdeathbirth 


\title{
deathbirth \\ death \\ the
}

Finally, in a fourth treatment one can resort to adjectives and the semanteme of existence (and its structural enabler non-existence, or death) in the form of the verb to be, which allows for the natural English way to say nasce. In this construction, to "be dead" is just one syntagm beyond dying. And, as in the previous cases, visual rhymes, typographical similarities, and the proliferation of /i/ are desirable, especially in the rendering of "se > se" as "be > be." This last alternative may in fact best communicate the cyclical "ontological" strangeness of the original, and thus it should come last and cycle back to the first.

\author{
be \\ born \\ be dead be born \\ be dead be born be dead
}

reborn redead reborn

redead reborn

redead

re

\begin{aligned} \multicolumn{1}{c}{ deborn } \\ dedead deborn \\ dedead deborn dedead \\ \\ \\ borndeadborn \\ deadborn \\ dead \\ be \end{aligned}

Ideally, one could post this set, these four interrelated versions-translations, on facing pages or on one large page, side by side, one on top of the other, in the four corners of a large square or rectangle, simulating the poem-placards for Brazil's National Exhibition of Concrete Art in 1956 (cf. simulation appended). Geometrically, one would be quadrangulating the triangles of words (with their own combinations of three and four). Being able to have all four renderings at once, to avoid the exclusivity clauses of 
conventional translation compacts, which require there to be but one translation at a time, permits one to bypass the vexation of "choose and lose.” To be so inclusive in special cases, such as this "nascemorre" by Haroldo de Campos, may bring sui generis results and satisfaction. At least for the sake of argument, having a four-pronged rendering of this one poem may be a unique instance of transcriação, or of one of its variants, which could, depending on the composition, be justifiable in other instances of creative translinguistic interpretation of the intricately woven verbivocovisual ideograms of poesia concreta brasileira. A quadrilateral translation is also figuratively intersemiotic, with a multilateral graphic representation moving to a new dimension. 


\section{References}

BRITTO, Paulo Henriques (2004) “Augusto de Campos como tradutor.” In Sobre Augusto de Campos. Flora Süssekind and Júlio Castañón Guimarães, eds. Rio de Janeiro: 7Letras/Fundação Casa de Rui Barbosa. 323-43.

CAMPOS, Haroldo de (2007 [1963]) “Translation as Creation and Criticism.” NOVAS:

Selected Writings. Antonio Sergio Bessa and Odile Cisneros, eds. and trans. Evanston, Ill.: Northwestern University Press. 312-26.

(1989) “Da tradução à transficcionalidade.” 34 letras 3, 82-85. (1977 [1969]) “A quadratura do círculo.” In A arte no horizonte do provável. São Paulo: Perspectiva. 121-28.

CLÜVER, Claus (2007) “The Noigandres Poets and Concrete Art.” Ciberletras 17 (www.lehman.edu). No pagination.

(1979) "Brazilian Concrete: Painting, Poetry, Time, and Space." Proceedings of IXth Congress of the International Comparative Literature Association. Innsbruck: AMOE. 207-19.

JAKOBSON, Roman (2000 [1959]) “On Linguistic Aspects of Translation.” In Lawrence Venuti, ed. The Translation Studies Reader. London and New York. 113-18.

MOLINA, José (2008) "Poundharoldian hubris: translighting the art of poetry." Brasil/Brazil vol. 21, no. 38. 81-102.

PERRONE, Charles A. (1996) Seven Faces: Brazilian Poetry since Modernism. Durham, NC: Duke University Press.

PLAZA, Julio (1987) Tradução intersemiótica. São Paulo: Perspectiva.

SANTAELLA, Lucia (2005) "Transcriar, transluzir, transluciferar: a teoria da tradução de Haroldo de Campos.” In céu acima: para um tombeau de Haroldo de Campos. Leda Tenório da Motta, ed. São Paulo: Perspectiva. 221-32.

SARDUY, Severo (1986) “Towards Concreteness.” Trans. A. Simpson. Latin American Literary Review vol. 14, no. 27, 61-69.

SOLT, Mary Ellen, ed. (1970) Concrete Poetry: A World View. Bloomington: Indiana University Press.

VIEIRA, Else R. P. (1999) "Liberating Calibans: Readings of Antropofagia and Haroldo de Campos’ Poetics of Transcreation.” In Susan Basnett and Harish 
Triverdi, eds. Post-colonial Translation: Theory and Practice. London and New York: Routledge. 95-113.

WILLIAMS, Emmett (1967) An Anthology of Concrete Poetry. New York: Something Else Press. 


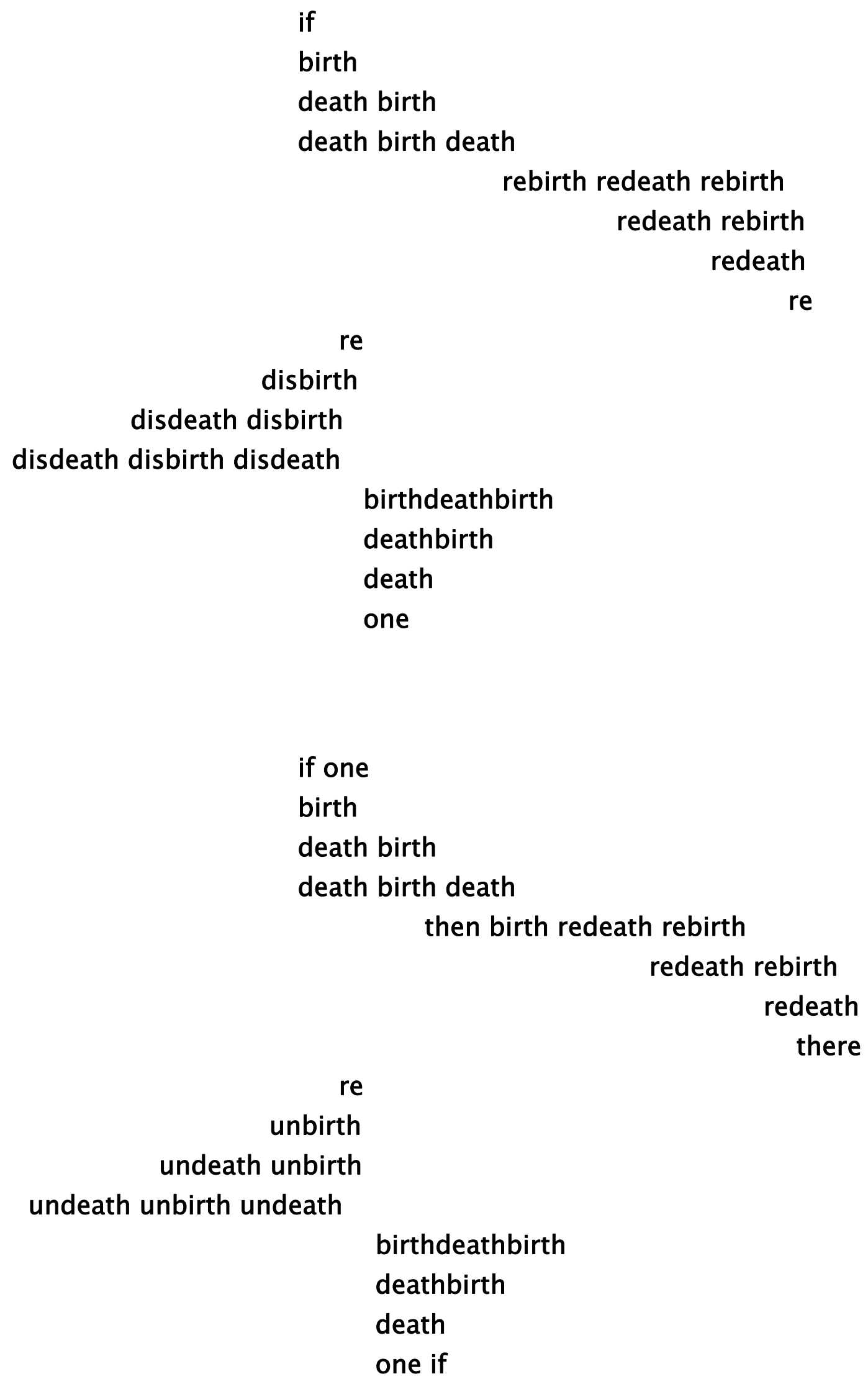




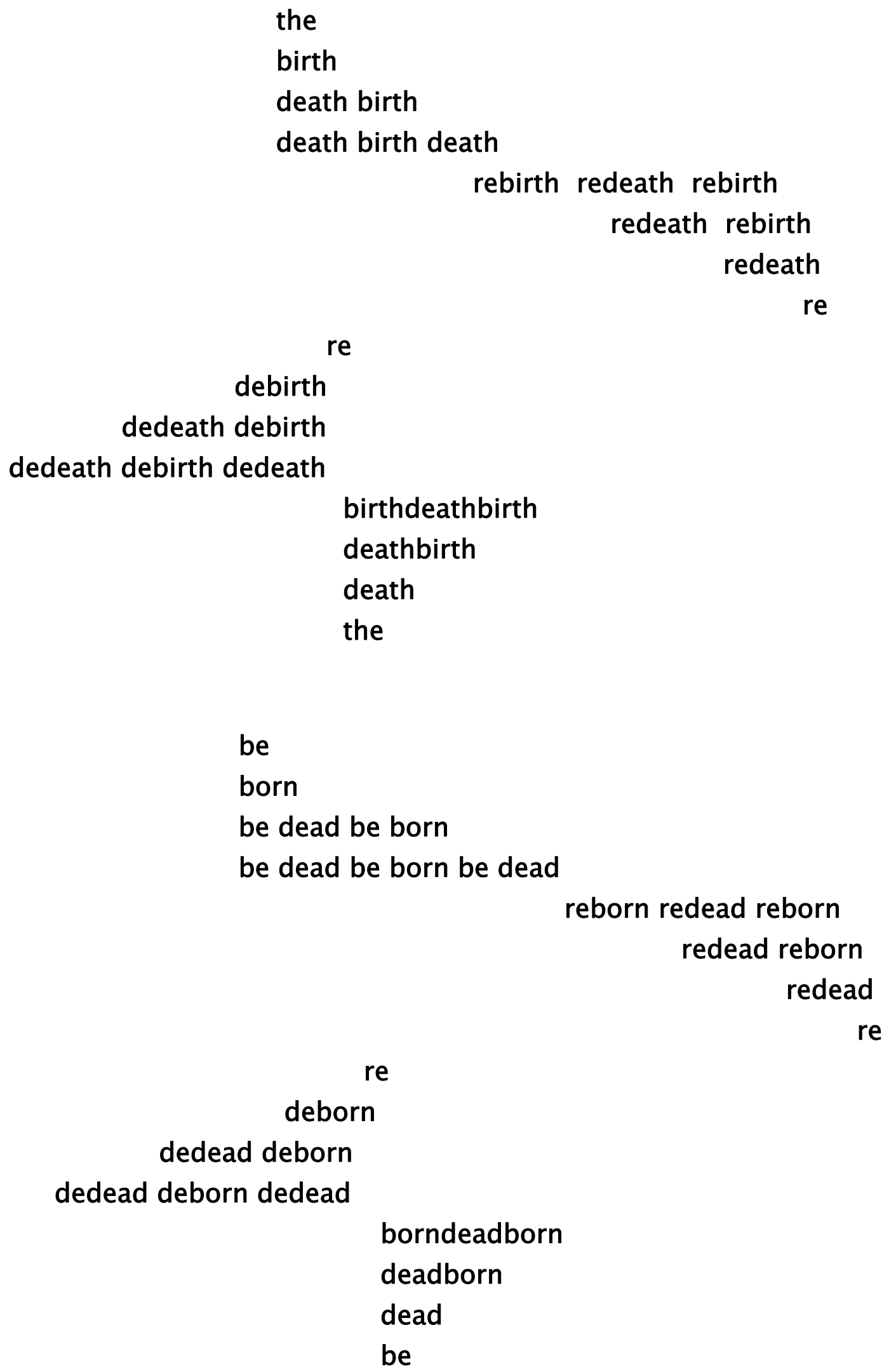

